\title{
Hydrolysis of whey proteins by proteases extracted from Cynara cardunculus and immobilized onto highly activated supports
}

Keywords: Enzyme; Cardosin; Agarose; Structural stabilization; Dairy foods; Hydrolase; Attachment

\author{
Estela M. Lamas ${ }^{\mathrm{a}}$, Rui M. Barros ${ }^{\mathrm{a}}$, Victor M. Balcão ${ }^{\mathrm{a}, \mathrm{b}}$, F. Xavier Malcata ${ }^{\mathrm{a}, *}$ \\ ${ }^{a}$ Escola Superior de Biotecnologia, Universidade Católica Portuguesa, Rua Dr. António Bernardino de Almeida, P-4200-072 Porto, Portugal \\ ${ }^{\mathrm{b}}$ Universidade Fernando Pessoa, Praça 9 de Abril, P-4249-004 Porto, Portugal
}

\begin{abstract}
Blends of cardosins A and B, enzymes present in aqueous extracts of the flowers of the thistle (Cynara cardunculus L.), have for long been used as rennets by the cheesemaking industry in the Iberian Peninsula. These dimeric proteases are present in the stigmæ and stylets of said flowers, and are thought to play a role in sexual reproduction of the plant. In the present research effort, production of cardosin derivatives (starting from a crude extract), encompassing full stabilization of their dimeric structure, has been attempted via covalent, multi-subunit immobilization onto highly activated agarose-glutaraldehyde supports. Boiling such enzyme derivatives in the presence of sodium dodecyl sulfate and $\beta$-mercaptoethanol did not lead to leaching of enzyme, thus proving the effectiveness of the attachment procedure. Furthermore, derivatives prepared under optimal conditions presented ca. half the specific activity of the enzyme in soluble form, and were successfully employed at lab-scale trials to perform (selective) hydrolysis of $\alpha$-lactalbumin, one of the major proteins in bovine whey.
\end{abstract}

\section{Introduction}

Crude extracts from the stigmæ and stylets of flowers of Cynara cardunculus L. are probably the most successful plant rennet known to date; they have been employed since ancient times in the farm level manufacture of traditional raw ovine milk cheeses in Portugal and bordering regions of Spain (Faro, 1991; Sousa, 1998). Aqueous extracts of dried flowers of $C$. cardunculus possess three acid proteases, currently termed cardosins (Heimgartner et al., 1990; Campos et al., 1990; Faro, 1991; Cordeiro et al., 1992); of those, forms I and II are similar to each other, and thus jointly denominated cardosin A, whereas form III is denominated cardosin B (Faro et al., 1992). Each cardosin consists of two subunits, with apparent molecular weights of $31 \mathrm{kDa}$ and 15 $\mathrm{kDa}$ for cardosin A, and $34 \mathrm{kDa}$ and $14 \mathrm{kDa}$ for cardosin $\mathrm{B}$ (Veríssimo et al., 1995, 1996). Esteves (1995) reported that cardosins A and B possess catalytic activities and specificities similar to those of chymosin and pepsin, respectively,

\footnotetext{
* Corresponding author.

E-mail address: xmalcata@esb.ucp.pt (F.X. Malcata).
}

which are the main components of animal rennets. This author also found that the drying process decreases the proteolytic activity of the crude extract, in particular the activity accounted for by cardosin B; since this is the stronger proteolytic enzyme in the thistle flower, said process will thus considerably affect the overall proteolytic activity of that rennet. In general, aspartic proteases cleave peptide bonds flanked by bulky hydrophobic amino acid residues (Faro et al., 1992; Fox et al., 1994). The optimum pH of the crude extract is 5.1 at $37^{\circ} \mathrm{C}$ (Heimgartner et al., 1990), 5.7 at $37^{\circ} \mathrm{C}$ (Campos et al., 1990), and 6.0 at $50^{\circ} \mathrm{C}$ (Faro, 1991), provided that $\kappa$-casein is employed as substrate. Most such enzymes are catalytically unstable in the alkaline $\mathrm{pH}$ range, thus affecting their usefulness as cheesemaking coagulants (Green, 1977). Like other milk-clotting enzymes (e.g. chymosin), proteases from $C$. cardunculus are able to cleave specific peptide bonds in bovine $\kappa$-casein (Macedo et al., 1993), viz. Phe ${ }_{105}-\mathrm{Met}_{106}$, thus yielding para- $\kappa$-casein and a soluble macropeptide; this is the first (and rate-controlling) step in enzyme-mediated coagulation of milk. The great majority of such macropeptide is lost in the whey upon syneresis, yet para- $\kappa$-casein is incorporated into the cheese curd matrix. 
Whey, the most important by-product of the dairy industry, may have a potential high-added value owing to its high protein content; however, it is a major pollutant because of its BOD, which raises serious environmental implications if it is disposed of into public sewage systems and fresh water ponds. About $80 \%$ of the protein inventory of whey consists of $\beta$-lactoglobulin $(\beta$ - Lg), with a molecular weight of 36 $\mathrm{kDa}$, and $\alpha$-lactalbumin $(\alpha-\mathrm{La})$, with a molecular weight of $14.2 \mathrm{kDa}$; both these proteins are rich from a nutritional standpoint, owing to their amino acid residue profile (Pintado, 1999).

Enzymatic hydrolysis of whey protein concentrates may eventually lead to more digestible and functional peptides; when incorporated into food formulae, they bring about favorable contributions to texture and taste, as well as reduction of allergenic effects (Asselin et al., 1988; Schmidt and Poll, 1991; Boza et al., 1995). Since those enzymes are relatively expensive to obtain, development of strategies that will produce structural and functional stabilization thereof via immobilization may increase their industrial applicability, namely in bioreactors that convert the proteins in dairy industry effluents to fermentable nitrogen sources; by doing so, the structural stabilization would prevent release of enzyme-subunits to the effluent (thus greatly decreasing the risks of environmental contaminations), whereas the functional stabilization would increase the useful life of the bioreactor device (hence decreasing operating costs).

Agarose gels are quite popular because they are almost ideal supports for the preparation of matrices in affinity chromatography and enzyme immobilization. Agarose beads consist of a three-dimensional network of highly hydrophilic and extremely inert fibers, the surface of which is essentially covered by hydroxyl groups; these groups can easily be activated for covalent immobilization of enzymes, thus providing a high specific area for immobilization (Medin, 1995; Penzol et al., 1998; Fernández-Lafuente et al., 1999; Balcão et al., 2001a,b). In the present research work, cardosins present in dried flowers of $C$. cardunculus were covalently attached onto highly activated agarose supports, which were used to catalyze the direct hydrolysis of cow's whey.

\section{Materials and methods}

\subsection{Materials}

2.1a. Enzymes. The enzymes used consisted of a crude blend of cardosins A and B, as they occur in nature, after aqueous extraction of flowers of $C$. cardunculus $\mathrm{L}$.

2.1b. Chemicals. Agarose beads (6BCL and 10BCL, i.e. $6 \%$ and $10 \%$ beads cross-linking, respectively) were obtained from HISPANAGAR (Burgos, Spain). Glycidol (2,3-epoxy-1-propanol), boric acid, lauryl sulfate (sodium dodecyl sulfate), $\beta$-mercaptoethanol, ammonium persulfate, sodium thiosulfate, TEMED $\left(\mathrm{N}^{\prime} \mathrm{N}^{\prime} \mathrm{N}^{\prime} \mathrm{N}\right.$-tetramethylethylenediamine), ethylenediamine, formaldehyde, TRIZMA ${ }^{\circledR}$ hydrochloride, Schiff's reagent (fuchsin-sulfate), sodium acetate trihydrate, sodium hydroxide, glycerol (87\% in water), sodium borohydride and a mixture of low molecular weight markers for electrophoresis-BSA (66 kDa), ovalbumin (45 $\mathrm{kDa}$ ), glyceraldehyde-3-phosphate dehydrogenase (36 $\mathrm{kDa})$, carbonic anhydrase (29 kDa), trypsinogen $(24 \mathrm{kDa})$, trypsin inhibitor $(20 \mathrm{kDa}), \alpha$-La $(14.2 \mathrm{kDa})$ and aprotinin $(6.5 \mathrm{kDa})$-were all purchased from Sigma (St. Louis MO, USA); $\mathrm{CCl}_{3} \mathrm{COOH}$ (TCA), $\mathrm{NaIO}_{4}, \mathrm{Na}_{2} \mathrm{HPO}_{4}, \mathrm{NaH}_{2} \mathrm{PO}_{4}$, $\mathrm{C}_{6} \mathrm{H}_{8} \mathrm{O}_{7} \cdot \mathrm{H}_{2} \mathrm{O}, \mathrm{C}_{6} \mathrm{H}_{5} \mathrm{Na}_{3} \mathrm{O}_{7}$ and $\mathrm{NaN}_{3}$ were purchased from Merck (Darmstadt, Germany). Glutaraldehyde aqueous solution $(25 \% \mathrm{v} / \mathrm{v})$ was purchased from Fluka (Steinheim, Germany). High density minigels, PhastGel SDS buffer strips, a mixture of low molecular weight standards for SDS-PAGE—phosphorylase B (94 kDa), BSA (67 kDa), ovalbumin (43 kDa), carbonic anhydrase (30 kDa), soybean trypsin inhibitor $(20.1 \mathrm{kDa})$ and $\alpha$-La $(14.4 \mathrm{kDa})$-and a mixture of molecular weight standards for FPLC - aldolase (158 kDa), BSA (67 kDa), ovalbumin (43 kDa), $\beta$-Lg (36 $\mathrm{kDa}), \alpha$-La (14.4 kDa) and ribonuclease $(13.7 \mathrm{kDa})$-were all purchased from Pharmacia LKB Biotechnology (Uppsala, Sweden). Filter paper $(0.22 \mu \mathrm{m})$ was purchased from Nalgene (New York NY, USA), and nonsterile filters (0.45 $\mu \mathrm{m})$ were purchased from Nucleopore (Cambridge MA, USA). Tap water was purified in a Milli-Q Plus 185 system (Molsheim, France) to a final conductivity of ca. 18.2 $\mathrm{M} \Omega$. $\mathrm{cm}^{-1}$. The solvents used were all analytical grade or better, and were used without further purification.

2.1c. Analytical equipment. All spectrophotometric readings were carried out using quartz cuvettes in an UV-VIS spectrophotometer from Shimadzu (Kyoto, Japan). The enzyme aqueous extract was lyophilized in a CHRIST ALPHA 1-4 freeze-dryer from Braun Biotech (Braunschweig, Germany). High density gels were run using a PhastSystem unit (Pharmacia LKB Biotechnology). SDS-PAGE was performed in a Protean II xi vertical slab-gel unit from Bio-Rad (Watford, UK), coupled with a model 1000/500 power supply also from Bio-Rad and a refrigerated water bath from Julabo Labortechnik (Seelbach, Germany). All electrophoresis gels were scanned in a GS-700 Imaging Densitometer from Bio-Rad (Hercules CA, USA) using the Molecular Analyst software (vs. 1.4) also from Bio-Rad. All support preparations and enzyme immobilization procedures were carried out in a Móvil Rod end-over-end agitator from Selecta (Barcelona, Spain). The FPLC system (Pharmacia LKB Biotechnology) consisted of two P-500 positive displacement pumps, an electrically powered MV-7 motorized valve, a gel filtration column pre-packed with Superose 12 HR 10/30 and an UVII single-path spectrophotometer monitor. Samples were passed through a $0.45 \mu \mathrm{m}$ filter and injected through a $100 \mu \mathrm{L}-$ loop. 
Table 1

Experimental layout for the batchwise hydrolysis of whey protein, catalyzed by the crude enzyme derivatives prepared

\begin{tabular}{|c|c|c|c|c|}
\hline Variable & $\begin{array}{l}\text { Proportion } \\
\text { Enzyme/substrate } \\
\left(\mathbf{E} / \mathbf{S}, m_{\text {immobilized protein }}\right. \\
\left.m_{\text {whey protein }}\right)\end{array}$ & $\begin{array}{l}\text { Mass of cardosin } \\
\text { derivative } \\
(\mathrm{mg})\end{array}$ & $\begin{array}{l}\text { Mass of lyophilized } \\
\text { whey protein } \\
\text { concentrate } \\
(\mathrm{mg})\end{array}$ & $\begin{array}{l}\text { Volume of } 100 \\
\mathrm{mM} \text { citrate buffer } \\
(\mathrm{pH} \mathrm{5.2)}(\mathrm{mL})\end{array}$ \\
\hline & $\mathbf{1} / \mathbf{1 0 0}, 9 / 900$ & 500 & 3600 & \\
\hline \multirow[t]{3}{*}{$\mathrm{E}$} & $\mathbf{1} / \mathbf{1 5 0}, 6 / 900$ & 333.3 & 3600 & \\
\hline & $\mathbf{1 / 3 0 0}, 3 / 900$ & 166.7 & 3600 & \\
\hline & $\mathbf{1} / \mathbf{7 5}, 6 / 450$ & 333.3 & 1800 & 50 \\
\hline \multirow[t]{2}{*}{$\mathrm{S}$} & $\mathbf{1} / \mathbf{1 5 0}, 6 / 900$ & 333.3 & 3600 & \\
\hline & $\mathbf{1 / 3 0 0}, 6 / 1800$ & 333.3 & 7200 & \\
\hline Control & - & - & 3600 & \\
\hline
\end{tabular}

E: enzyme, S: substrate.

\subsection{Experimental procedures}

2.2a. Preparation of enzyme extract. The crude enzyme extract was prepared by macerating ca. $7 \mathrm{~g}$ of stylets and stigmæ of dried flowers of C. cardunculus in $70 \mathrm{~mL}$ of 100 $\mathrm{mM}$ sodium citrate buffer ( $\mathrm{pH} 3.0$ ), as described by Faro (1991). After centrifugation at $10,000 \mathrm{~g}$ for $5 \mathrm{~min}$, the resultant supernatant was collected and further dialyzed at $4^{\circ} \mathrm{C}$ against a large volume of deionized water for $48 \mathrm{~h}$ (to remove citrate), using dialysis tubing with MW cutoff of 10 kDa (Sigma, St. Louis, MO, USA), and finally lyophilized.

2.2b. Preparation of enzyme substrates. Whey, obtained from bovine milk after regular cheesemaking, was first centrifuged at $3,000 \mathrm{~g}$ and $4^{\circ} \mathrm{C}$ (to eliminate residual fat) and subsequently ultrafiltered and lyophilized. Immediately before starting the experimental reactions, the lyophilized whey (containing $25 \%(\mathrm{w} / \mathrm{w})$ total protein) was reconstituted in experimental citrate buffer, according to the layout detailed in Table 1.

2.2c. Determination of total protein content of enzyme extract. The protein content of the crude extract was determined using the Micro Protein Determination kit No. 690 (Sigma).

2.2d. Determination of catalytic activity of enzyme extract. The proteolytic activity of the crude enzyme extract was determined based on the procedure described by Tomarelli et al. (1949), which involves digestion of azocasein (obtained from a casein chromophore and dinitrogenated arylamine) at $25^{\circ} \mathrm{C}$, thus producing coloured reaction products (that are soluble in trichloroacetic acid, TCA); absorbance of the supernatant, after centrifugation, was measured at $440 \mathrm{~nm}$.

2.2e. Evaluation of $p H$ stability of enzyme extract. To an aqueous buffered solution, that was $50 \%$ in aqueous $87 \%$ (v/v) glycerol at the desired $\mathrm{pH}$, ca. $12.5 \mathrm{mg} / \mathrm{mL}$ of crude (dialyzed and lyophilized) extract were dissolved, and the resulting $3.6 \mathrm{mg}_{\text {protein }} / \mathrm{mL}$ solution was incubated at either $4^{\circ} \mathrm{C}$ (when testing for $\mathrm{pH} 7$, the buffer was $25 \mathrm{mM}$ $\mathrm{NaH}_{2} \mathrm{PO}_{4}$ ) or $25^{\circ} \mathrm{C}$ (when testing for $\mathrm{pH} 10$, the buffer was $50 \mathrm{mM} \mathrm{NaHCO}$ ), for at least $2 \mathrm{~h}$. At these temperatures virtually no thermal deactivation of the crude extract preparation could be observed in the timeframe considered. At selected time intervals, and after thorough mixing, aliquots of both solutions were withdrawn and assayed for activity using the protocol described earlier.

2.2f. Preparation of glyoxyl-agarose supports for the enzyme extract. The procedure followed was that described by Guisán (1988), with slight modifications: $26.25 \mathrm{~g}$ of agarose beads (6BCL or 10BCL, previously washed with plenty of deionized water) were weighed into a plastic flask, and water was added to a final volume of $45 \mathrm{~mL}(0.7 \mathrm{~g}$ of agarose is roughly equivalent to $1 \mathrm{~mL}$ ). Following mild homogenization, $12.5 \mathrm{~mL}$ of $1.7 \mathrm{M} \mathrm{NaOH}$ containing 356 mg $\mathrm{NaBH}_{4}$ (acting as reducing agent) was added slowly. The flask was then placed in an ice bath, and glycidol was added dropwise (since it promotes a highly exothermic reaction) to a final concentration of $2 \mathrm{M}$ (i.e. $9 \mathrm{~mL}$ glycidol was added). The mixture was then paddle-agitated at room temperature (ca. $25^{\circ} \mathrm{C}$ ) for $15-18 \mathrm{~h}$, and the activated gel thus obtained was finally washed with $500 \mathrm{~mL}$ deionized water. To $26.25 \mathrm{~g}$ of activated gel (i.e. $37.5 \mathrm{~mL}_{\text {gel }}$ ), $1 \mathrm{~mL}$ of aqueous $100 \mathrm{mM} \mathrm{NaIO}_{4}$ per $\mathrm{mL}_{\text {gel }}$ was added (so as to reach the level of $100 \mu \mathrm{mol}_{\text {aldehyde groups }} / \mathrm{mL}_{\text {gel }}$ ). The gel was then suspended in water, to a final volume of $375 \mathrm{~mL}$, and oxidation was allowed to proceed for $1.5-2 \mathrm{~h}$ (with paddle agitation); after this time, the gel was washed with $500 \mathrm{~mL}$ of deionized water. Confirmation of the presence of aldehyde groups in the gel proceeded through addition of a few $\mathrm{mg}$ of (oxidized) gel to ca. $200 \mu \mathrm{L}$ of Schiff's reagent in an eppendorf, which produced the expected pinky-purple coloration.

2.2g. Preparation of agarose-glutaraldehyde supports for the enzyme extract. The procedure described by Guisán (1988) was again followed, with slight modifications: $25 \mathrm{~g}$ of glyoxyl-agarose gel (prepared according to the procedure described above) were weighed into a plastic beaker, and 
further added with $143 \mathrm{~mL}$ of $2 \mathrm{M}$ ethylenediamine (pH 10). Following mild paddle agitation for ca. $2 \mathrm{~h}, 1.429 \mathrm{~g}$ of $\mathrm{NaBH}_{4}$ was added, and the paddle agitation was pursued for an extra $2 \mathrm{~h}$. The (amino) gel thus obtained was then sequentially washed with $1000 \mathrm{~mL}$ of $0.1 \mathrm{M}$ sodium acetate (pH 4) (to eliminate sodium borohydride), $1000 \mathrm{~mL}$ of 0.1 $\mathrm{M}$ boric acid ( $\mathrm{pH}$ 9) (to reduce electrostatic interactions and eliminate excess ethylenediamine), and finally plenty of deionized water. To $2.5 \mathrm{~g}$ of this amino gel, $2.8 \mathrm{~mL}$ of 200 $\mathrm{mM} \mathrm{NaH}{ }_{2} \mathrm{PO}_{4}$ was added and the $\mathrm{pH}$ of the resulting mixture was adjusted to 7 using diluted $\mathrm{NaOH} ; 4.2 \mathrm{~mL}$ of aqueous $25 \%(\mathrm{v} / \mathrm{v})$ glutaraldehyde was then added, and the $\mathrm{pH}$ of the resulting solution was adjusted once again to 7 . The mixture was subsequently paddle-agitated overnight in a gentle fashion, and the resulting gel was washed with 500 $\mathrm{mL}$ deionized water.

2.2h. Immobilization of enzyme extract onto agarose-glutaraldehyde supports. The preparation of these derivatives followed the procedure described by Balcão et al. (2001a, b); it encompassed addition of $16 \mathrm{~mL}$ aqueous $87 \%$ (v/v) glycerol into a plastic flask, followed by homogenization with $16 \mathrm{~mL}$ of $25 \mathrm{mM} \mathrm{NaH} \mathrm{PO}_{4}$ (pH 7). To the resulting solution, $200 \mathrm{mg}$ of dialyzed and lyophilized crude extract was added. Following mild homogenization, $2 \mathrm{~g}$ of agaroseglutaraldehyde (6BCL or 10BCL, after activation with 40 $\left.\mu \mathrm{mol}_{\text {aldehyde groups }} / \mathrm{mL}_{\text {gel }}\right)$ was added to this solution, and the flask stoppered tightly and placed in an end-over-end agitator kept at $4^{\circ} \mathrm{C}$. Samples of both the suspension and the supernatant were regularly withdrawn and assayed for activity, together with the blank (which consisted of a $4 \mathrm{~mL}$ sample of reconstituted extract solution, withdrawn prior to addition of the support). In order to discontinue the immobilization procedure (when the activity of the supernatant was sufficiently low), the derivative was reduced via addition of $1 \mathrm{mg} \mathrm{NaBH}_{4}$ per $\mathrm{mL}$ of gel (to transform the Schiff's bases obtained into covalent bonds, therefore strengthening the bonds between enzyme and support), followed by mild paddle-agitation for ca. $30 \mathrm{~min}$. After this period, the derivative was washed with $500 \mathrm{~mL}$ of deionized water.

2.2i. Analysis of immobilized enzyme extract. The stabilization of the quaternary structure of the dimeric cardosins was checked by electrophoresis, after having boiled the derivatives in the presence of SDS. This treatment, suggested by Fernández-Lafuente et al. (1999a), releases from the support any enzyme subunit that was not covalently bound to it; therefore, the presence of bands in the stained gel would indicate lack of stabilization.

2.2j. Hydrolysis of enzyme model substrate. Reduction of the derivatives after termination of the immobilization procedure proved to be a key point in maintaining their activity; in fact, if the non-reacted groups on the surface of the support were not reduced, the immobilized enzyme molecules would continue to interact with them, eventually un- folding and therefore becoming inactivated. The model reaction system was prepared by resuspending $770 \mathrm{mg}$ of derivative (reduced and non-reduced) in $10 \mathrm{~mL}$ of $25 \mathrm{mM}$ $\mathrm{NaH}_{2} \mathrm{PO}_{4}(\mathrm{pH} 7.0)$ at $25^{\circ} \mathrm{C}$, followed by addition of $500 \mu \mathrm{L}$ of azocasein aqueous solution $(25 \mathrm{mg} / \mathrm{mL}$ in a $50 \mathrm{mM}$ histidine solution, $\mathrm{pH}$ 6.0). At the same time, a blank was prepared simply by resuspending the same amount of derivative (reduced and non-reduced) in $25 \mathrm{mM} \mathrm{NaH}_{2} \mathrm{PO}_{4}$ (pH $7.0)$, at $4^{\circ} \mathrm{C}$, in another reaction vessel. Reactions were allowed to proceed at $25^{\circ} \mathrm{C}$ in both reaction vessels. At selected time intervals, aliquots were withdrawn and $1 \mathrm{~mL}$ TCA $(5 \% \mathrm{w} / \mathrm{v})$ was added to each aliquot; the resulting solution was centrifuged at $6,000 \mathrm{rpm}$ for $10 \mathrm{~min}$, the supernatant was then poured into quartz cuvettes, and absorbance was read at $440 \mathrm{~nm}$.

$2.2 k$. Hydrolysis of enzyme whey substrate. These reactions were performed batchwise, employing variable amounts of both enzyme derivatives and substrate up to the same overall volume of reaction medium, according to Table 1 . Since the derivatives, using agarose(6BCL)-glutaraldehyde or agarose(10BCL)-glutaraldehyde, were prepared by making available $200 \mathrm{mg}$ of crude extract (ca. 30\% (w/w) protein) to the support, and since the yield of immobilization was ca. $30 \%$ protein, irrespective of the type of support, one obtains an amount of immobilized protein of ca. $9 \mathrm{mg}_{\text {protein }} / \mathrm{g}_{\text {support }}$. All reactions were performed at $55^{\circ} \mathrm{C}$ and $\mathrm{pH} 5.2$, in a water bath equipped with an orbital shaker set at $100 \mathrm{rpm}$. Samples were withdrawn in duplicate at selected time intervals, and duly prepared for both SDS-PAGE and FPLC analyses. Samples $(1 \mathrm{~mL})$ withdrawn for SDS-PAGE analysis were immediately added with $100 \mu \mathrm{L}$ of $10 \%$ (w/v) SDS in an eppendorf vial, and heated to $95^{\circ} \mathrm{C}$ for $10 \mathrm{~min}$. After cooling down to room temperature, the vials containing the denatured samples were frozen and subsequently centrifuged at $10,000 \mathrm{rpm}$ for $5 \mathrm{~min}$. Samples $(1.5 \mathrm{~mL})$ withdrawn for FPLC analysis were immediately frozen at $-80^{\circ} \mathrm{C}$ and stored at that temperature until analysis.

\section{2l. Electrophoresis of immobilized enzyme extracts. High} density gel electrophoresis was performed with both agarose-glutaraldehyde derivatives, as well as with selected low molecular weight standards, using a PhastSystem unit and high density minigels $(50 \mathrm{~mm}$ high $\times 43 \mathrm{~mm}$ wide $\times 0.45$ $\mathrm{mm}$ thick). For the preparation of immobilized enzyme samples, pre-determined amounts of each cardosin derivative were placed in separate eppendorf vials, and $100 \mu \mathrm{L}$ of $10 \%(\mathrm{w} / \mathrm{v})$ SDS was added (to ensure elimination of shape and charge effects). The vials were subsequently heated at $90^{\circ} \mathrm{C}$ for $10 \mathrm{~min}$ in a heating block, and finally cooled to near room temperature. Approximately $4 \mu \mathrm{L}$ of solution of denatured sample or markers, as appropriate, were poured in lined small pools before application onto the gel surface. After electrical resolution of the sample proteins, the gels were transferred to the development section of the PhastSystem unit and duly stained with Coomassie blue R-250. 
2.2m. Electrophoresis of enzyme substrates. For the preparation of samples, $500 \mu \mathrm{L}$ of the reaction medium (withdrawn at regular time intervals) was poured into eppendorf vials, into which $100 \mu \mathrm{L}$ of $10 \%$ (w/v) SDS was further added. The vials were subsequently heated at $90^{\circ} \mathrm{C}$ for ca. $10 \mathrm{~min}$ in a boiling water bath, cooled to near room temperature and centrifuged at $10,000 \mathrm{rpm}$ for $10 \mathrm{~min}$. The solution containing SDS, $\beta$-mercaptoethanol, sucrose and bromophenol blue was added to the supernatant of said samples, and incubated in a heating block at $90^{\circ} \mathrm{C}$ for $5 \mathrm{~min}$. The $15 \%$ polyacrylamide gel slabs $(\mathrm{pH} 8.6)$, containing $0.1 \%(\mathrm{w} / \mathrm{v})$ SDS, were prepared and run using the discontinuous buffer system of Laemmli (1970), at constant voltage $(100 \mathrm{~V})$, constant current $(70 \mathrm{~mA})$ and constant temperature $\left(19^{\circ} \mathrm{C}\right)$ for $10 \mathrm{~h}$; after this time, the gels were stained with Coomassie blue R-250. All gels were scanned using a green filter, in a GS-700 imaging densitometer, and further analysed using the image analysis software Molecular Analyst, in order to identify and quantify the protein(s).

2.2n. Liquid chromatography of enzyme substrates. The reaction samples were assayed by Fast Protein Liquid Chromatography (FPLC), according to the procedure described by Pintado and Malcata (1996). At pre-selected time intervals, $1.5 \mathrm{~mL}$ aliquots were withdrawn from the reaction medium, poured into eppendorf vials and immediately frozen at $-80^{\circ} \mathrm{C}$. Right before analysis, the vials were thawed and the contents filtered through $0.45 \mu \mathrm{m}$ nylon membrane filters. Aliquots $(100 \mu \mathrm{L})$ of the clear filtered solution were then promptly injected onto the FPLC column, and eluted with a mobile phase $(150 \mathrm{mM} \mathrm{NaCl}$ in $0.05 \mathrm{M}$ aqueous phosphate buffer, $\mathrm{pH} 7.0$, containing $0.2 \mathrm{~g} / \mathrm{L} \mathrm{NaN}_{3}$ as preservative) at a flow rate of $0.4 \mathrm{~mL} / \mathrm{min}$ for $80 \mathrm{~min}$. The mobile phase was filtered through $0.22 \mu \mathrm{m}$ paper filter. Detection of the proteins in the eluate was by absorbance at $280 \mathrm{~nm}$. The retention times of the peaks obtained were compared with those of a mixture of molecular weight standards. Quantitative calibration of the column, in terms of bovine whey proteins, was performed using various dilutions of an aqueous solution containing $4.10 \mathrm{mg} / \mathrm{mL} \beta-\mathrm{Lg}$, $9.10 \mathrm{mg} / \mathrm{mL} \alpha-\mathrm{La}, 6.80 \mathrm{mg} / \mathrm{mL}$ BSA, $0.10 \mathrm{mg} / \mathrm{mL}$ orotic acid and $0.020 \mathrm{mg} / \mathrm{mL}$ uric acid. The void volume of the column was determined using blue dextran (retention time of ca. $19.5 \mathrm{~min}$ ). Each analytical determination was carried out in duplicate.

\section{Results and discussion}

3.1a. Preparation of enzyme extract. Special care was exercised so as to minimize variations during preparation of the crude extracts. Therefore, several batches of crude extract (obtained via manual grinding and subsequent aqueous extraction) were prepared in different days, and all those extracts were eventually mixed together, and further dialyzed and lyophilized.

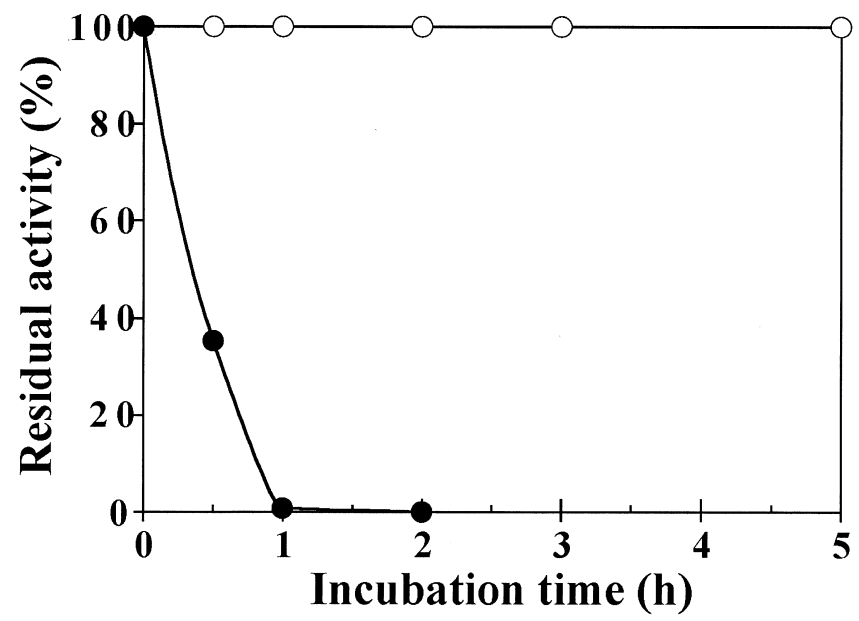

Fig. 1. Evolution of the fractional activity remaining throughout incubation of buffered solutions of crude enzyme extract at pH $7(\bigcirc)$ and pH $10(\bullet)$.

3.1b. Determination of catalytic activity of enzyme extract. These assays were based on the standard procedure described by Tomarelli et al. (1949); owing to the large number of intermediate steps involved, an intrinsically high variability was produced, as noted and commented upon by Figueiredo (1987).

3.1c. Evaluation of $p H$ stability of enzyme extract. The results pertaining to stability of the crude blend of cardosins versus $\mathrm{pH}$ are depicted in Fig. 1. Previous experience indicated that proteases are not apparently sensitive to shear stress, when acting in free form in a batch stirred tank reactor under the rotational rates employed; therefore, it is not expected that our deactivation data reflected mechanical, rather than thermal deactivation. Furthermore, if one considers that the increase of the inner area of the vortex caused by magnetic stirring is negligible and no extensive

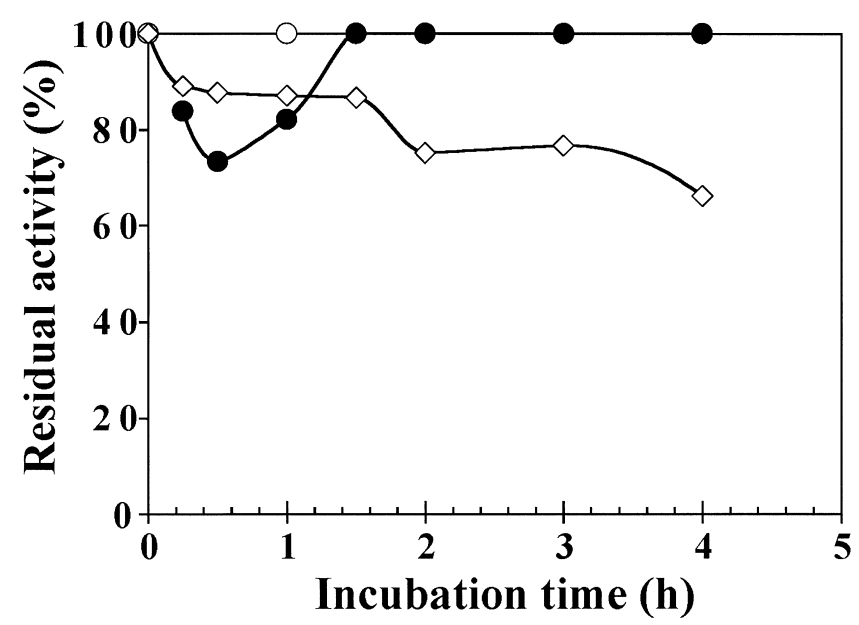

Fig. 2. Evolution of the fractional activity remaining throughout covalent immobilization of the crude blend of cardosins onto agarose(6BCL)-glutaraldehyde supports, activated with $40 \mu \mathrm{mol}_{\text {aldehyde groups }} / \mathrm{mL}$ gel , for the blank $(\bigcirc)$, the suspension $(\bullet)$ and the supernatant $(\diamond)$. 


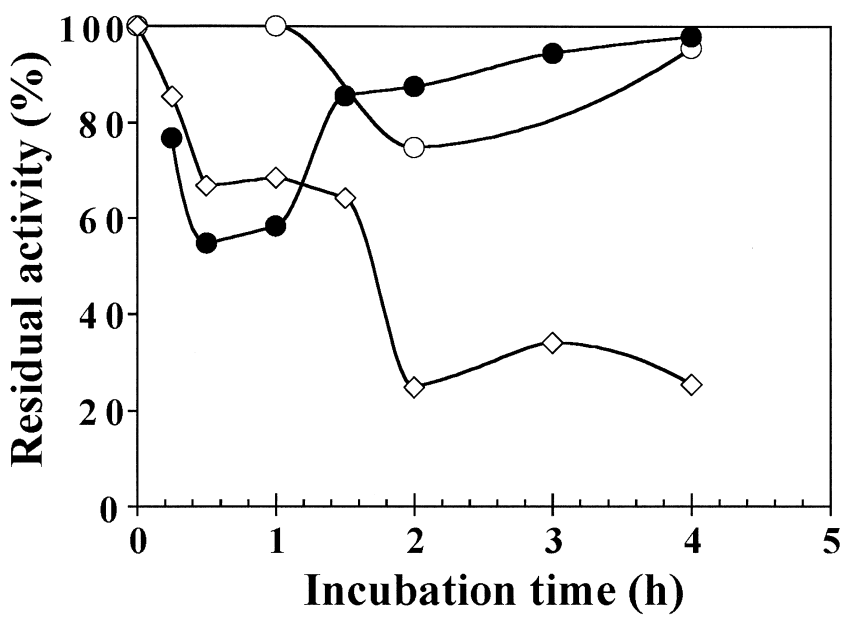

Fig. 3. Evolution of the remaining fractional activity during covalent immobilization of the crude blend of cardosins onto agarose(10BCL)glutaraldehyde supports, activated with $40 \mu \mathrm{mol}_{\text {aldehyde groups }} / \mathrm{mL}_{\text {gel }}$, for the blank (○), the suspension $(\bigcirc)$ and the supernatant $(\diamond)$.

foam forms (as was the case), then denaturation of both cardosins caused by adsorption onto the high surface tension air/water interface was likely negligible. The decay in proteolytic activity at $\mathrm{pH} 10$ can thus safely be attributed to $\mathrm{pH}$-driven changes in the proper ionic form of the amino acid residues actually involved in catalysis. Furthermore, the high alkalinity of the environment (when incubation took place at $\mathrm{pH}$ 10) usually leads to distortion of the three-dimensional architecture of the enzyme. A close inspection of Fig. 1 indicates that both cardosins had virtually no activity after incubation for $1 \mathrm{~h}$ at $\mathrm{pH} 10$. Such realization precluded attempts to immobilize the cardosins in highly-activated glyoxyl-agarose supports (Guisán, 1988; Balcão et al., 2001a).

3.1d. Immobilization of enzyme extract onto agarose-glutaraldehyde supports. The results obtained in the course of immobilization of the crude enzyme extract onto highly activated agarose-glutaraldehyde supports are displayed in Fig. 2 for 6\% agarose beads cross-linking, and in Fig. 3 for $10 \%$ agarose beads cross-linking. When performing this type of enzyme immobilization, a milder $\mathrm{pH}$ (viz. 7) exists in the microenvironment made available to the enzyme, so the native form of both cardosins remains unchanged prior to contacting the (highly activated) support. This type of glutaraldehyde-activated support reacts primarily with the terminal amino residue of proteins (Guisán, 1988). When the activation degree is high, as was the case in this research effort (see Figs. 2 and 3), and the enzyme is allowed to contact the support for a long time (say, longer than $2 \mathrm{~h}$ ), more bonds will be established between enzyme and support (Blanco et al., 1989), which requires longer reaction times, possibly owing to difficulties in aligning correctly the enzyme surface and the activated groups on the surface of the agarose fibers (Fernández-Lafuente et al., 1999a).

When using agarose-glutaraldehyde supports (Fernán-

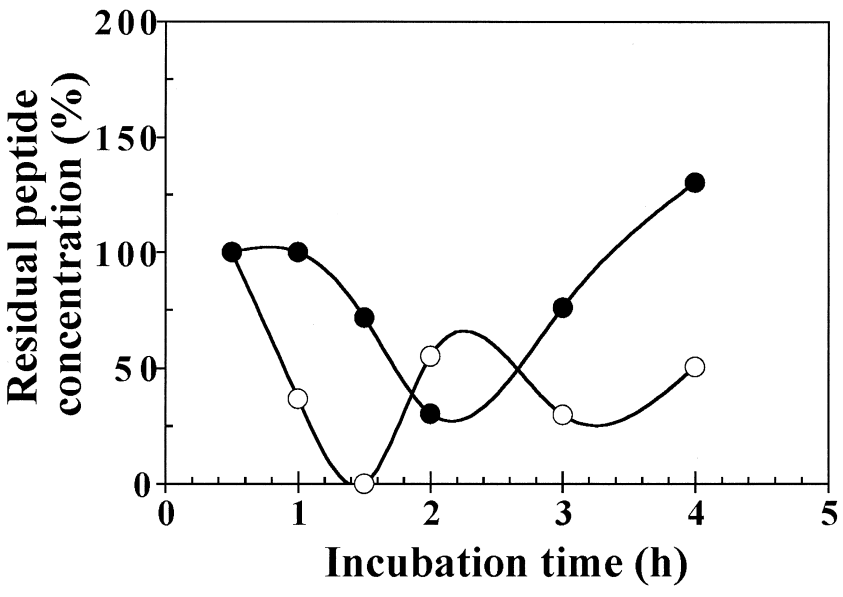

Fig. 4. Evolution of the residual peptide concentration throughout hydrolysis of azocasein as catalyzed by non-reduced $(\bigcirc)$ and reduced $(O)$ agarose(6BCL)-glutaraldehyde derivatives.

dez-Lafuente et al., 1995), with the environment set at low ionic strength (as was actually the case), the enzyme molecules will first adsorb onto the support through the negatively charged portions of its surface, and will then react through their terminal amino group. The rate of immobilization was high at low ionic strength, as can be noticed from inspection of Figs. 2 and 3; this observation can be explained, at least to some extent, by fast initial adsorption of both enzymes onto the support.

The derivatives prepared with thicker agarose fibers (i.e. with agarose 10BCL) contain apparently much enzyme immobilized (see Fig. 3); however, the thicker the fibers, the smaller the pores, so less void space will be available inside the beads, thus leading to higher diffusional limitations upon the transport of substrates. This assertion was supported when performing batch hydrolysis (of either synthetic or real protein substrates) with both types of crude enzyme derivatives, as one notices from inspection of Figs. $5,7 \mathrm{a}, 7 \mathrm{c}, 7 \mathrm{e}$ and $7 \mathrm{~g}$.

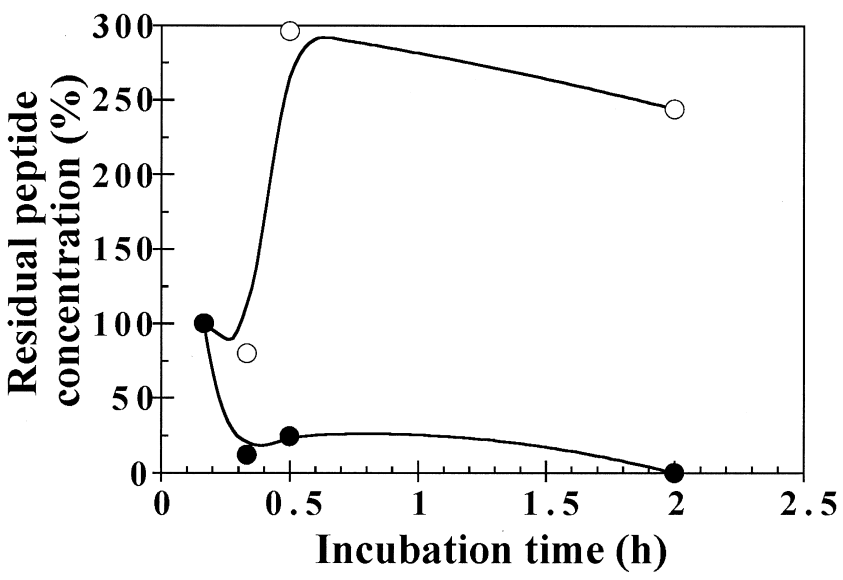

Fig. 5. Evolution of the residual peptide concentration throughout hydrolysis of azocasein as catalyzed by reduced agarose(6BCL)-glutaraldehyde derivatives $(\bigcirc)$ and reduced agarose(10BCL)-glutaraldehyde derivatives 


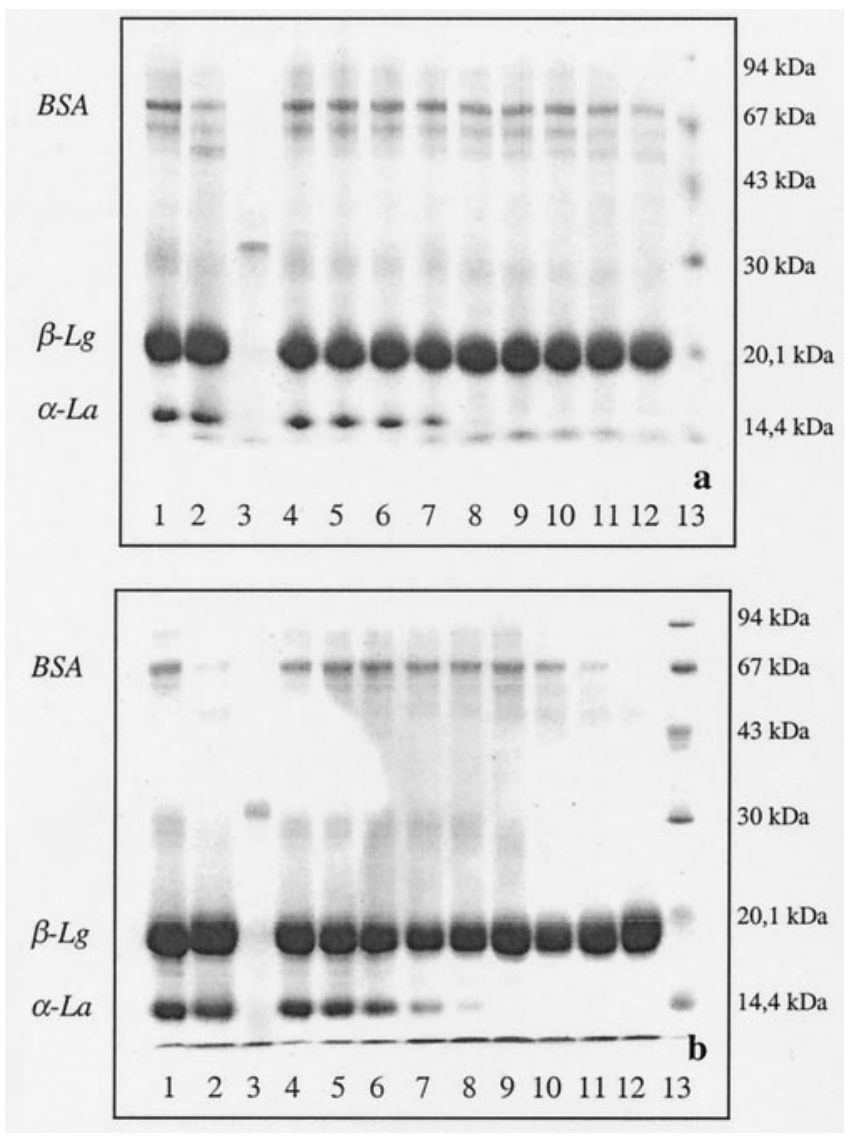

Fig. 6. SDS-PAGE electrophoretograms of molecular weight markers (lane 13), controls at the beginning (lane 1) and by $24 \mathrm{~h}$ of reaction (lane 2), and samples withdrawn at selected time intervals, viz. $0 \mathrm{~h}$ (lane 4 ), $0.5 \mathrm{~h}$ (lane 5), 1 h (lane 6), 2 h (lane 7), 5 h (lane 8), 8 h (lane 9), 12 h (lane 10), 24 h (lane 11) and $48 \mathrm{~h}$ (lane 12), for reactions catalyzed by cardosins immobilized on agarose 6BCL (a) and agarose 10BCL (b).

As can be observed from inspection of Figs. 2 and 3, the activity of the free enzyme solution did not decay during the time frame of the immobilization trials. Also, the percent activity of the enzyme derivative (see Fig. 2), obtained as the difference between the activity of the suspension and that of the supernatant, was $30 \%$ by the end of the immobilization time frame, whereas the blank kept the initial activity intact (see Fig. 2). When using agarose 10BCL (see Fig. 3), again the activity of the free enzyme solution did not decay significantly during the time frame of the immobilization trials. The percent activity of the enzyme derivative (see Fig. 3) was ca. $70 \%$ by the end of the immobilization time frame, whereas the blank exhibited ca. $95 \%$ of its initial activity (see also Fig. 3). This means that the derivative possesses ca. $66.5 \%$ of the activity of the initial enzyme solution. These results are in close agreement with those reported by Balcão et al. (2001a,b), Fernández-Lafuente et al. (1999a), Blanco and Guisán (1989), and Blanco et al. (1989).

The results obtained when performing batch hydrolysis of azocasein, using reduced and non-reduced agarose 6BCL cardosin derivatives, are displayed in Fig. 4. When deriva- tives were not reduced, activity (expressed in terms of relative peptide concentration) was rather low, probably because time elapsing allows more bonds to form as the enzyme remains in contact with non-reduced (hence highly reactive) groups on the surface of the support. This behaviour could promote a slight distortion of the three-dimensional topology of the enzyme, thereby leading to inactivation of some of the enzyme molecules already immobilized (Blanco and Guisán, 1989); this might explain (at least partially) the higher activity of the reduced derivatives. For this reason, all derivatives were deliberately reduced after the immobilization procedure was complete.

The electrophoretic analysis of the supernatants, obtained after boiling the free enzyme solution and the various enzyme derivatives in the presence of $\beta$-mercaptoethanol and SDS (results not shown), did not reveal any bands whatsoever in the lanes corresponding to the derivatives; therefore, evidence was provided for the irreversibility of the immobilization procedure. The first steps in the inactivation of multimeric enzymes are usually associated with the dissociation of subunits, and consequent conformational changes. In this work, full stabilization of the quaternary assembly of cardosins was achieved via immobilization onto highly activated agarose-glutaraldehyde supports. Bearing in mind that protein molecules attached to the support, even via a single covalent bond, cannot be desorbed by the aforementioned treatment, any band appearing in the gel should in fact be associated with subunits of the dimeric enzyme molecules that were not covalently attached to the support (Fernández-Lafuente et al., 1999a).

3.1e. Hydrolysis of enzyme model substrate. The results generated regarding hydrolysis of a model protein (azocasein), as catalyzed by both enzyme derivatives, are displayed in Fig. 5. It can be assumed that (multipoint) covalent attachment between a pre-existing support and a protein molecule greatly enhances its stability (Guisán et al., 1993; Fernández-Lafuente and Guisán, 1998). On this basis, one can also rationalize that when only a small area of the protein surface (say, 10-20\%) is involved in covalent attachment, stability will also be enhanced because a great rigidification of such a small area will be able to translate the stabilization effect to the whole structure of the protein molecule; in fact, it all depends on the environment under which covalent binding is attained. As can be observed from inspection of Fig. 5, hydrolysis of azocasein proceeded to a great extent when utilizing the crude enzyme derivative obtained with agarose 6BCL, unlike that using agarose 10BCL. These results were somewhat expected, notwithstanding the fact that 10BCL agarose beads allowed immobilization of a greater amount of enzyme (see Fig. 3). However, the combined effect of both the branched structure of azocasein and the smaller size of the void spaces also led to enhanced diffusional limitations. This very same trend was found when hydrolysis of whey protein concentrate (WPC) was attempted (as seen below). 

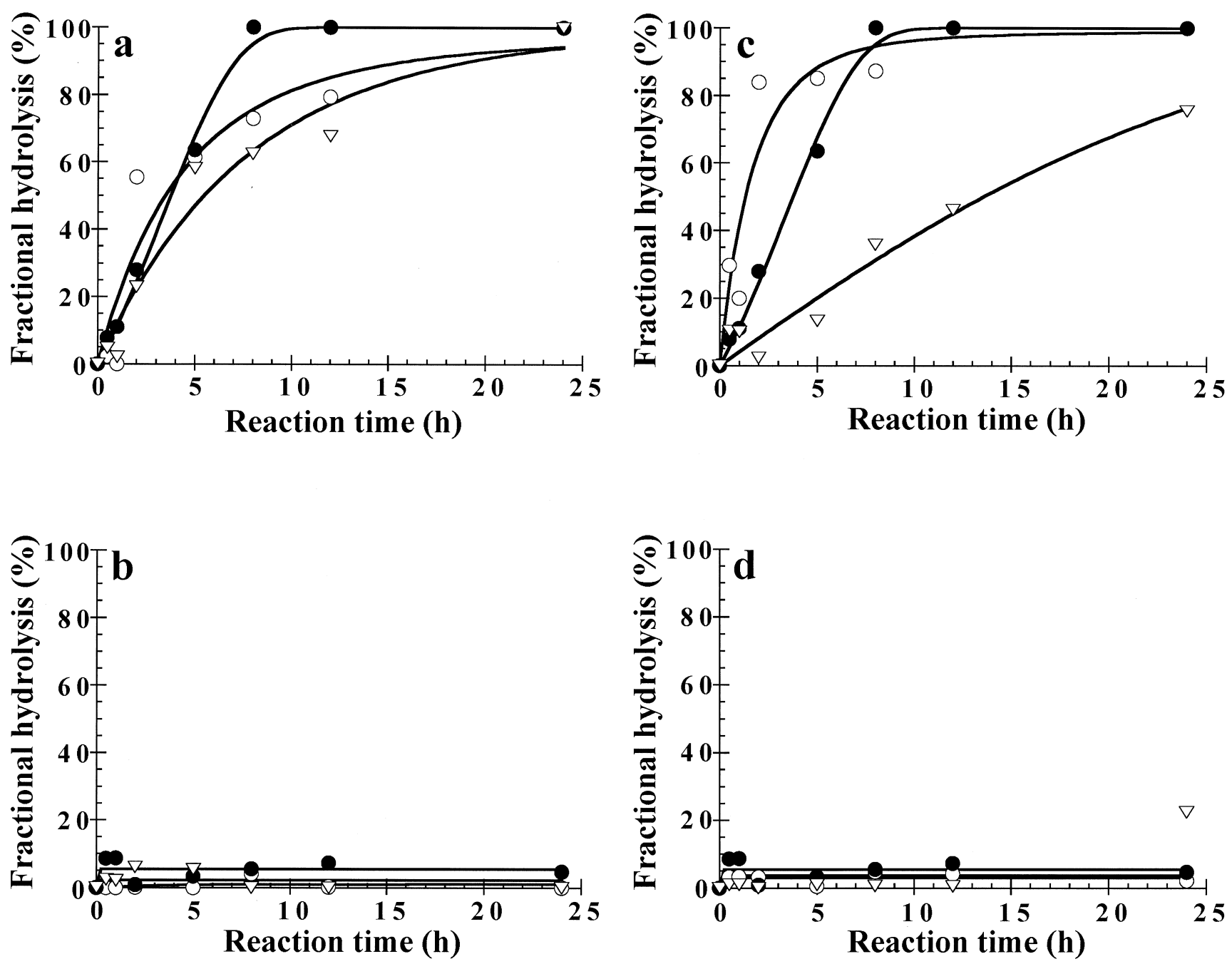

Fig. 7. Evolution of the fractional hydrolysis of $\alpha$-lactalbumin $(\alpha-\mathrm{La})$ and $\beta$-lactoglobulin $(\beta$-Lg), when performing batch hydrolysis in a reaction system consisting of whey protein concentrate, employing both types of crude cardosin derivatives, with variation of enzyme concentration for a fixed substrate concentration. For the agarose(6BCL)-glutaraldehyde derivative: (a) hydrolysis of $\alpha$-La at 1/100 (O), 1/150 ( $)$ and 1/300 ( $\nabla)$; and (b) hydrolysis of $\beta$-Lg at $1 / 100(\bigcirc), 1 / 150(\bullet)$ and $1 / 300(\nabla)$. For the agarose(10BCL)-glutaraldehyde derivative: (e) hydrolysis of $\alpha$-La at $1 / 100(\bigcirc), 1 / 150(\bullet)$ and $1 / 300(\nabla)$; and (f) hydrolysis of $\beta$ - $\operatorname{Lg}$ at $1 / 100(\bigcirc), 1 / 150(\bullet)$ and $1 / 300(\nabla)$. With variation of substrate concentration for a fixed enzyme concentration, for the

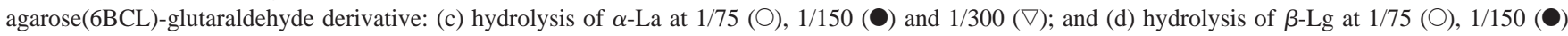
and 1/300 ( $\nabla)$. For the agarose(10BCL)-glutaraldehyde derivative: (g) hydrolysis of $\alpha$-La at 1/75 (O), 1/150 ( $)$ and 1/300 ( $\nabla)$; and (h) hydrolysis of $\beta$-Lg at $1 / 100(\bigcirc), 1 / 150(\bullet)$ and $1 / 300(\nabla)$.

3.1f. Hydrolysis of enzyme whey substrate. The results obtained encompassing hydrolysis of WPC are displayed in Figs. 6, 7 and 8. Observation of these data indicates that full hydrolysis of $\alpha$-lactalbumin is achieved when the cardosins were immobilized on 6BCL agarose (see Figs. 6a, 7a, 7c and $8 \mathrm{a}$ ), but not when they were immobilized on 10BCL agarose (see Figs. 6b, 7e, 7g and 8b). The later derivatives led to a maximum of ca. $80 \%$ hydrolysis in the same timeframe, whereas the former reached $100 \%$ hydrolysis. In addition, only $\alpha$-La is hydrolyzed, with $\beta$ - $\mathrm{Lg}$ remaining virtually unaffected (see Figs. 7b, 7d, 7f and 7h). These results are interesting in that immobilization of a crude blend of cardosins leads to selective hydrolysis of $\alpha$-La. Cardosin A has indeed been shown to possess a high affinity towards $\alpha$-La $\left(\mathrm{k}_{\text {cat }}=0.102 \mathrm{~s}^{-1}\right)$ at $\mathrm{pH} 5.2$ (Barros and Malcata, 2001); these authors also reported that the $\mathrm{k}_{\mathrm{cat}} / \mathrm{K}_{\mathrm{m}}$ ratio lies between 0.42 and 4.20 for $\alpha$-La, and between 0.000 and 0.064 for $\beta$ - $\mathrm{Lg}$, thus making it apparent that the crude blend of cardosins exhibits higher affinity for $\alpha$-La than for $\beta$-Lg. This represents a major advantage if only $\alpha$-La were to be degraded by cardosin A (Barros and Malcata, 2001); in fact, it implies that no preliminary preparative chromatography, which is highly time-costing and reagent-consuming, would be needed in order to isolate such cardosin from the crude extract. When the amount of derivative was increased for the same amount of substrate (see Figs. 7a, 7b, 7e and 7f), higher degrees of hydrolysis were achieved with the 10BCL derivative (see Fig. 7e). However, 

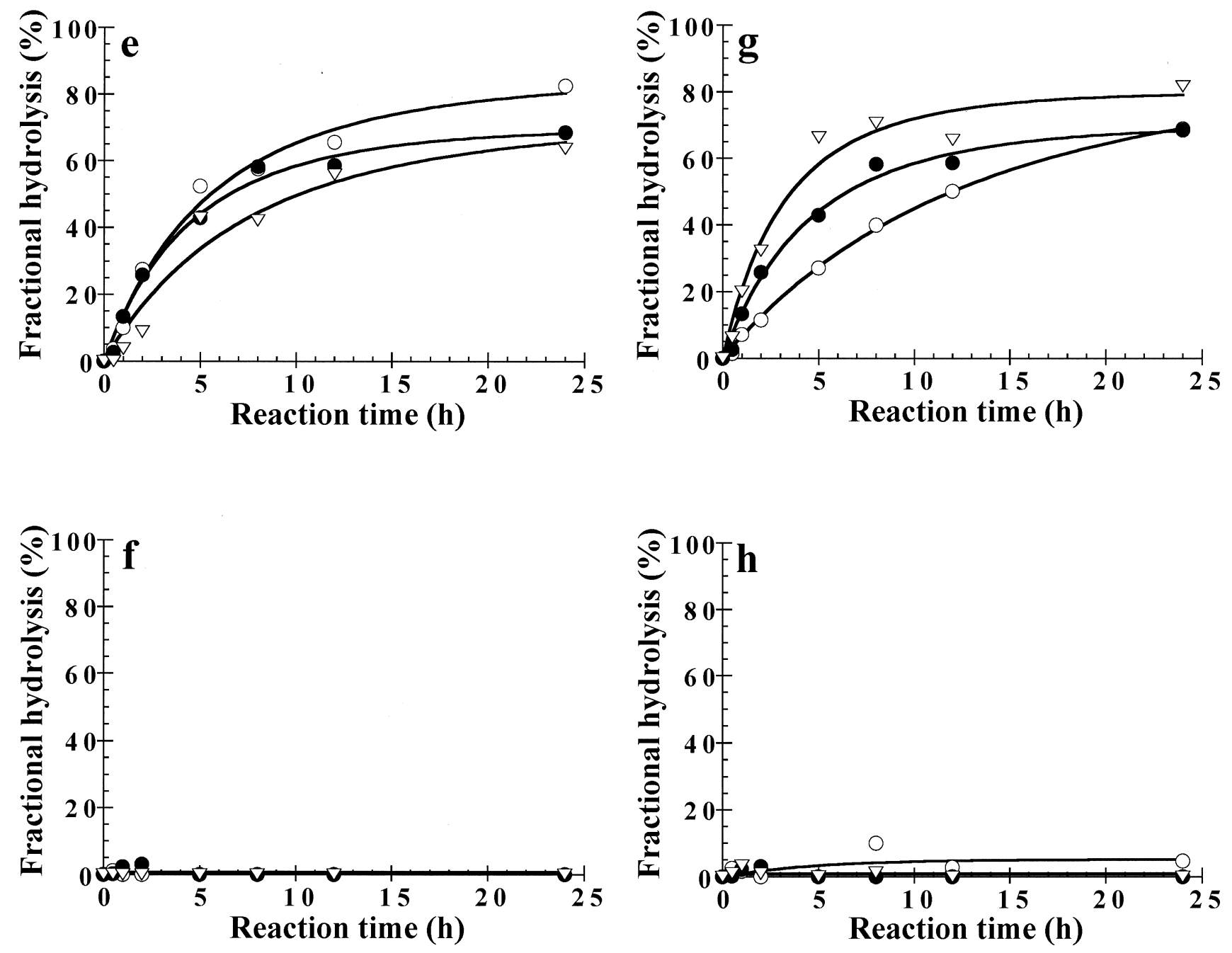

Fig. 7. (Continued)

the maximum conversion with the 6BCL derivative was achieved at the intermediate substrate-to-enzyme ratio (see Fig. 7a).

When increasing the ratio of whey protein to enzyme derivative, a reversed trend was noticed; this might be attributed to the joint effect of saturation of the enzyme active site and presence of diffusional limitations. Said claim was checked with the 6BCL derivative (see Fig. 7c), for which the higher conversion was attained for both 1:75 and 1:150 weight ratios of enzyme:substrate. Increasing further this ratio yielded saturation of the enzyme, with concomitant enhancement of resistance to molecular transport. Since the 6BCL derivative was prepared with agarose beads possessing thinner fibers, and therefore wider void spaces, this observation was anticipated. The opposite was verified, however, when the 10BCL derivative was employed. In this case, the substrate molecules faced enhanced steric hindrance at the pore mouth; hence, saturation of the enzyme was never possible, yet the increase in substrate concentration in the reaction medium by a 4-fold factor improved the conversion factor by only ca. 10\% (see Fig.
$7 \mathrm{~g})$. Inspection of Figs. 7a, 7c, 7e and $7 \mathrm{~g}$ also indicates that the rates of reaction were higher when reactions were catalyzed by the cardosin 6BCL derivatives than when they were catalyzed by the 10BCL derivatives.

\section{Conclusions}

Use of highly activated, biocompatible agarose-glutaraldeyde as support for immobilization of a crude blend of cardosins allows full functional stabilization of their dimeric, three-dimensional architecture; the (nano)environment of each molecule of cardosin will thus be virtually free from steric hindrance arising from the low molecular weight of the substrate ( $\alpha$-lactalbumin) while, at the same time, it allows selective hydrolysis of that protein in whey.

\section{Acknowledgments}

Financial support for RMB was through a Ph.D. fellowship by FCT (PRAXIS XXI BD/16037/98) and for VMB 

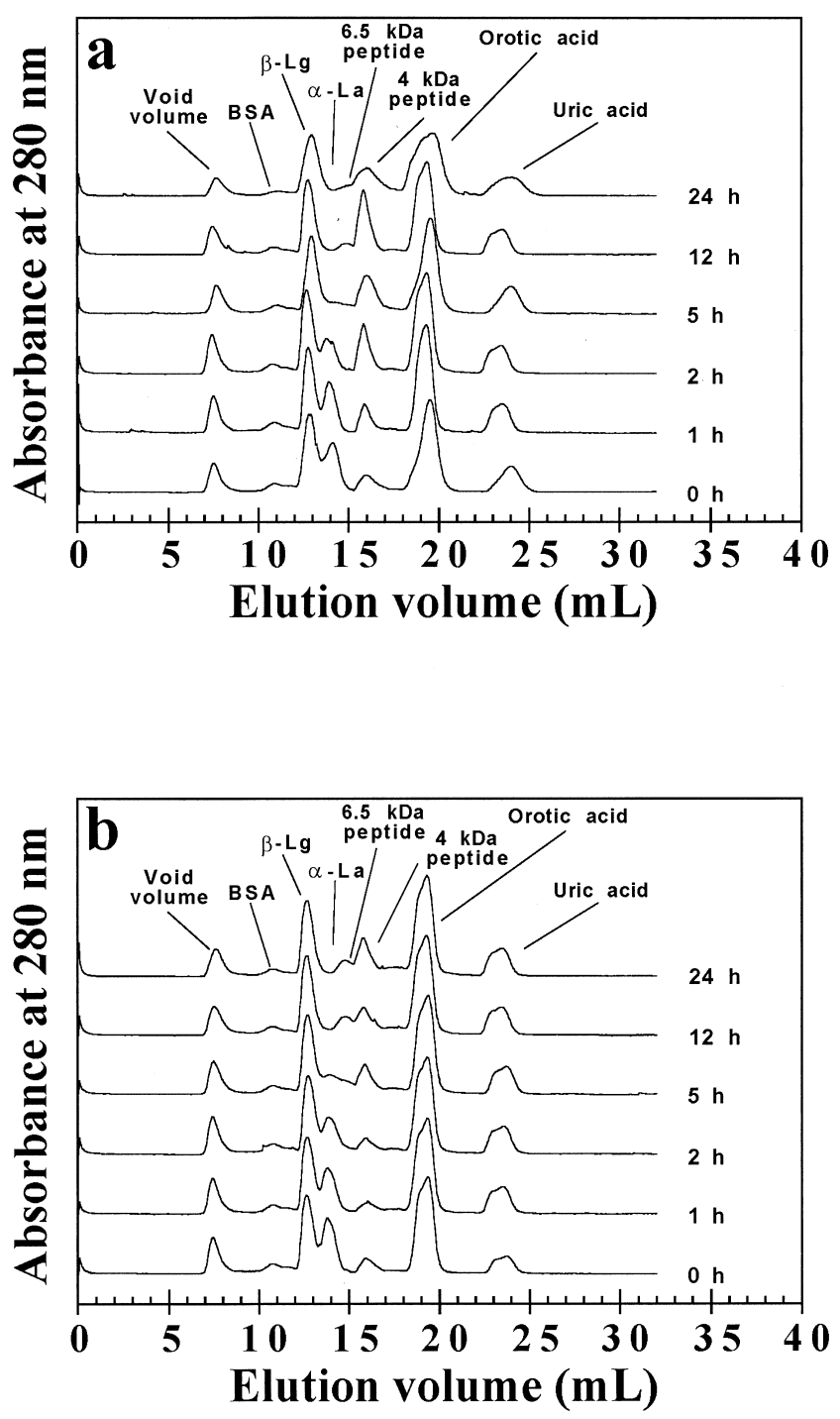

Fig. 8. Normalized FPLC profiles of the hydrolysis of whey protein when using cardosins immobilized on agarose 6BCL (a) and agarose 10BCL (b).

was through a Post-Doc fellowship also by FCT (PRAXIS XXI BPD/16388/98). The authors are grateful to Dr. José Manuel Guisán and Dr. Roberto Fernández-Lafuente (both affiliated with ICP/CSIC, Madrid) for technical help.

\section{References}

[1] Faro C. Purificação e caracterização fisico-química da protease de Cynara cardunculus L. Ph.D. thesis 1991, Universidade de Coimbra, Portugal.

[2] Sousa MJCF. Characterization of the proteolytic action of the flowers of Cynara cardunculus in ovine, caprine and bovine cheeses. Ph.D. thesis 1998, Escola Superior de Biotecnologia, Porto, Portugal.

[3] Heimgartner U, Pietrzak M, Geertsen R, Brodelius P, Silva-Figueiredo AC, Pais MSS. Purification and partial characterization of milk clotting proteases from flowers of Cynara cardunculus. Phytochemistry 1990;29:1405-10.

[4] Campos R, Guerra R, Aguiar M, Ventura O, Camacho L. Chemical characterization of proteases extracted from wild thistle (Cynara cardunculus). Food Chem 1990;35:89-97.
[5] Cordeiro MC, Jakob E, Puhan Z, Pais MS, Brodelius PE. Milk clotting and proteolytic activities of purified cynarases from Cynara cardunculus - a comparison to chymosin. Milchwissenschaft 1992; 47:681-748.

[6] Faro CJ, Moir AJ, Pires EV. Specificity of a milk-clotting enzyme extracted from the thistle Cynara cardunculus L.: action on oxidized insulin and $\kappa$-casein. Biotechnol Lett 1992;14:841-6.

[7] Veríssimo P, Esteves C, Faro C, Pires E. The vegetable rennet from Cynara cardunculus L. contains two proteinases with chymosin and pepsin-like specificities. Biotechnol Lett 1995;17:621-6.

[8] Veríssimo P, Faro C, Moir AJ, Lin Y, Tang J, Pires E. Purification, characterization and partial amino acid sequencing of two new aspartic proteinases from fresh flowers of Cynara cardunculus L. Eur J Biochem 1996;235:762-8.

[9] Esteves C. Estudo comparativo das características bioquímicas dos coalhos de Cynara cardunculus L., Cynara scolymus L., e Cynara humilis L. M.Sc. thesis 1995, Universidade de Coimbra, Portugal.

[10] Fox PF, Singh TK, McSweeney PLH. Proteolysis in cheese during ripening. In: Biochemistry of Milk Products, Varley J, Andrews AT, editors. Royal Society of Chemistry, Cambridge, UK, 1994. p. 1-31.

[11] Green ML. Review on the progress of dairy science: milk coagulants. J Dairy Res 1977;44:159-88.

[12] Macedo I, Faro CJ, Pires EV. Specificity and kinetics of the milkclotting enzyme from Cardoon (Cynara cardunculus L.) toward bovine $\kappa$-casein. J Agric Food Chem 1993;41:1537-40.

[13] Pintado MME. Characterization and application of wheys from native breeds: protein and technological aspects. Ph.D. thesis 1999, Escola Superior de Biotecnologia, Porto, Portugal.

[14] Asselin J, Amiot J, Gauthier SF, Mourad W, Herbert J. Immunogenicity and allergenicity of whey protein hydrolysates. J Food Sci 1988;53:1208-11.

[15] Schmidt DG, Poll JK. Enzymatic hydrolysis of whey proteins. Hydrolysis of $\alpha$-lactalbumin and $\beta$-lactoglobulin in buffer solutions by proteolytic enzymes. Neth Milk Dairy J 1991;45:225-40.

[16] Boza JJ, Martinez-Augustin O, Gil A. Nutritional and antigenic characterization of an enzymatic protein hydrolyzate. J Agric Food Chem 1995;43:872-5.

[17] Medin AS. Studies on structure and properties of agarose. Ph.D. thesis 1995, Uppsala University, Sweden.

[18] Penzol G, Armisén PA, Fernández-Lafuente R, Rodés L, Guisán JM. Use of dextrans as long and hydrophilic spacer arms to improve the performance of immobilized proteins acting on macromolecules. Biotechnol Bioeng 1998;60:518-23.

[19] Fernández-Lafuente R, Rosell CM, Caanan-Haden L, Rodés L, Guisán JM. Facile synthesis of artificial enzyme nano-environments via solid-phase chemistry of immobilized derivatives: dramatic stabilization of penicillin acylase versus organic solvents. Enz Microb Technol 1999b;24:96-103.

[20] Balcão VM, Mateo C, Fernández-Lafuente R, Malcata FX, Guisán JM. Structural and functional stabilization of L-asparaginase via multi-subunit immobilization onto highly activated supports. Biotechnol Prog 2001a [in press].

[21] Balcão VM, Mateo C, Fernández-Lafuente R, Malcata FX, Guisán JM. Coimmobilization of L-asparaginase and glutamate dehydrogenase onto highly activated supports. Enz Microb Technol 2001b [in press].

[22] Tomarelli R, Charney M, Harding M. The use of azoalbumin as a substrate in the colorimetric determination of peptic and tryptic activity. J Lab Clin Med 1949;34:428-33.

[23] Guisán JM. Aldehyde-agarose gels as activated supports for immobilization-stabilization of enzymes. Enz Microb Technol 1988;10: $375-82$.

[24] Fernández-Lafuente R, Rodriguez V, Mateo C, Penzol G, HernandezJustiz O, Irazoqui G, Villarino A, Ovsejevi K, Batista F, Guisán JM. Stabilization of multimeric enzymes via immobilization and post-immobilization techniques. J Mol Catal B: Enzymatic 1999a; 7:181-9. 
[25] Laemmli UK. Cleavage of structural proteins during the assembly of the head of bacteriophage T4. Nature 1970;227:680-5.

[26] Pintado MME, Malcata FX. Effect of thermal treatment on the protein profile of whey from ovine and caprine milk throughout lactation. Int Dairy J 1996;6:497-518.

[27] Figueiredo ACS. Cultura de células de Cynara cardunculus: produção de biomassa e obtenção de proteases. M.Sc. thesis 1987, Universidade de Lisboa, Lisboa, Portugal.

[28] Blanco RM, Calvete JJ, Guisán JM. Immobilization-stabilization of enzymes; variables that control the intensity of the trypsin (amino)-agarose (aldehyde) multipoint attachment. Enz Microb Technol 1989;11:353-9.

[29] Fernández-Lafuente R, Rosell CM, Rodriguez V, Guisán JM. Strategies for enzyme stabilization by intramolecular cross-linking with bifunctional reagents. Enz Microb Technol 1995;17:517-23.
[30] Blanco RM, Guisán JM. Stabilization of enzymes by multipoint covalent attachment to agarose-aldehyde gels: Borohydride reduction of trypsin-agarose derivatives. Enz Microb Technol 1989;11:360-6.

[31] Fernández-Lafuente R, Guisán JM. Enzyme and protein engineering via immobilization and post-immobilization techniques. Recent Res Devel Biotechnol Bioeng 1998;1:299-309.

[32] Guisán JM, Blanco RM, Fernández-Lafuente R, Rosell CM, Álvaro G, Bastida A. Enzyme stabilization by multipoint covalent attachment to activated pre-existing supports. In: Protein Stability and Stabilization. van den Tweel WJJ, Harder A, Buitelaar RM, editors. Elsevier, 1993. p. 55-62.

[33] Barros RM, Malcata FX. Modelling the kinetics of whey protein hydrolysis brought about by enzymes from Cynara cardunculus. J. Agric. Food Chem. [submitted]. 